\title{
Новий безпечний спосіб введення першого (оптичного) порту при виконанні симультанних комбінованих операцій при поєднанні симптомної жовчнокам'яної хвороби та лівобічної пахової грижі
}

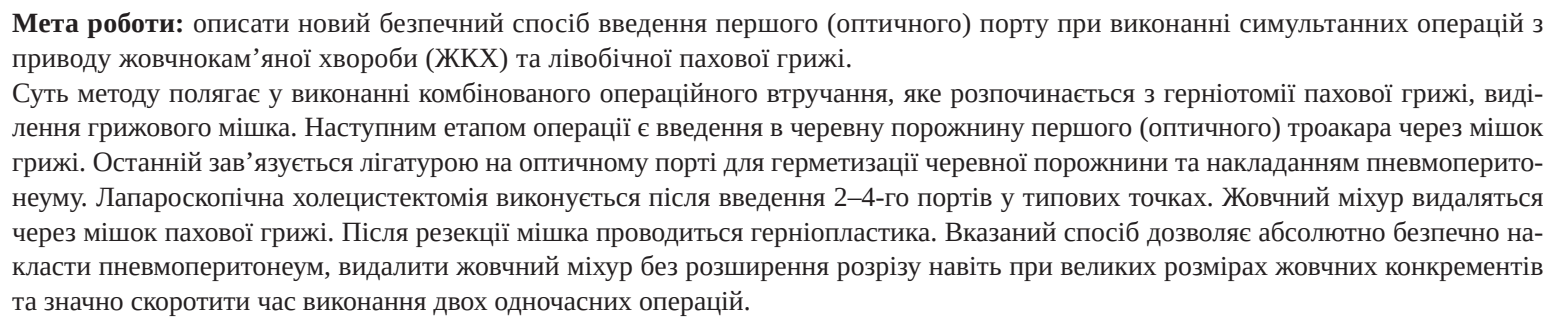

Мета роботи: описати новий безпечний спосіб введення першого (оптичного) порту при виконанні симультанних операцій з приводу жовчнокам’яної хвороби (ЖКХ) та лівобічної пахової грижі.

Суть методу полягає у виконанні комбінованого операційного втручання, яке розпочинається з герніотомії пахової грижі, виділення грижового мішка. Наступним етапом операції є введення в черевну порожнину першого (оптичного) троакара через мішок грижі. Останній зав’язується лігатурою на оптичному порті для герметизації черевної порожнини та накладанням пневмоперитонеуму. Лапароскопічна холецистектомія виконується після введення 2-4-го портів у типових точках. Жовчний міхур видаляться через мішок пахової грижі. Після резекції мішка проводиться герніопластика. Вказаний спосіб дозволяє абсолютно безпечно накласти пневмоперитонеум, видалити жовчний міхур без розширення розрізу навіть при великих розмірах жовчних конкрементів та значно скоротити час виконання двох одночасних операцій.

Ключові слова: безпечний пневмоперитонеум; перший порт; симультанні операції; лапароскопічна холецистектомія; пахова грижа.

31987 р., коли Дюбуа виконав першу лапароскопічну холецистектомію, кількість ЛХЕ щорічно зростає. Це пов’язано як зі збільшенням кількості хворих на ЖКХ, так і з розвитком техніки.

На сьогодні більшість районних лікарень Хмельницької області забезпечена ендовідеоскопічною апаратурою. При виконанні лапароскопічних операцій перед хірургом завжди постає питання щодо безпечного накладання карбоксиперитонеуму. Пункція голкою Вереша, троакаром чи відкритий спосіб не є стовідсотково безпечними. Ускладнення виникають при 0,5 \% ЛХЕ. Незважаючи на поширення методик SILS та NOTES, ЛXE з 3-4-портового доступу виконується найчастіше.

Окрему проблему становить вибір точки введення “оптичного” порту при використанні “0”-градусної оптики для візуалізації підпечінкового простору і при полярних антропометричних та конституційних параметрах пацієнтів. У високорослих хворих із брахіморфним типом тулуба та аліментарно-конституційним ожирінням (AKO) III-IV ступенів перший троакар встановлюється між мечоподібним відростком та пупком, у низькорослих хворих із доліхоморфним типом тулуба (“коротка” передня черевна стінка) перший троакар встановлюється між пупком та лобковим симфізом. Видалення жовчного міхура із великими конкрементами потребує розширення однієї із ран передньої черевної стінки.

Наявність у пацієнта двох та більше хірургічних захворювань часто ставить перед хірургом завдання їхньої одночасної корекції.

Симультанні лапароскопічні операційні втручання поділяються на: 1) симультанні операції $з$ лапароскопічного доступу; 2) симультанні ком- біновані лапароскопічні операції; 3) симультанні поєднані лапароскопічні операції.

У доступній медичній літературі статті про симультанні операційні втручання з приводу ЖКХ та інших гриж передньої черевної стінки (ПЧС) не рідкість, операції виконуються суто лапароскопічним чи комбінованим способом (лапароскопічний етап + герніопластика з окремого доступу після ЛХЕ).

З 1.01.2014 до 31.12.16 р. у хірургічному відділі Славутської центральної районної лікарні виконано 330 лапароскопічних холецистектомій.

Симультанні операції при поєднанні ЖКХ та грижі ПЧС виконано у 27 хворих (пупкова грижа - 25 випадків, післяопераційна вентральна грижа після нижньо-серединної лапаротомії - 2 випадки). Перший порт встановлювався через грижовий мішок в усіх випадках. Аутопластику грижі виконано в 24 хворих, алопластику - у 3 хворих. Видалення жовчного міхура через грижовий мішок проведено в 19 випадках. Ускладнень не було.

В одному випадку виникла необхідність проведення симультанної операції хворій із поєднанням симптомної ЖКХ та лівобічної пахової грижі. Ситуація визначила потребу в нестандартному підході до проведення операційного втручання в такому клінічному випадку.

Клінічне спостереження. Хвора С., віком 78 років, МКСХ № 1680, переведена 02.03.16 в хірургічний відділ Славутської центральної районної лікарні з терапевтичного відділення після купіруваного нападу жовчної коліки та дообстеження із діагнозом “ЖКХ. Хронічний калькульозний холецистит. Холедохолітіаз? Вентильний камінь холедоха? Лівобічна пахова грижа великих розмірів". 
Локальні дані: у лівій паховій ділянці визначається м'який, еластичний утвір діаметром до 14 см, який деформує ліву статеву губу та вільно вправляється в черевну порожнину. Симптом “кашльового поштовху” позитивний. Поверхневе пахове кільце діаметром до 4,5 см.

УЗД ОЧП від 01.03.16: жовчний міхур містить множинні дрібні конкременти, холедох - 12,5 мм. УЗД контроль від 03.03.16: холедох - 9 мм, у дистальному відділі нечітко визначається утвір розміром 3,5 мм. 04.03.16 - ЕРПХГ: ВДС розміщений у дивертикулі, панкреатична протока 1-2 мм, холедох 7-8 мм, конкрементів не містить. Контрастований жовчний міхур містить дрібні конкременти.

Анатомо-конституційні особливості хворої:

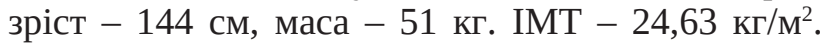
Відстані: т. Кера - пупок - 8 см, т. Кера - верхній край лобкового симфізу - 14 см, мечоподібний відросток - верхній край лобкового симфізу 22 cм, т. Kepa - tub. pubicum sin. - 20 cм.

07.03.16 р. проведено операцію: герніотомію пахової грижі зліва, лапароскопічну холецистектомію, аутопластику пахової грижі. Інструментальне забезпечення: ЛС “ТЕKNO”, оптика - “0” градусів - 10 мм.

Етапи операційного втручання:

1. Герніотомія в лівій паховій ділянці з виділенням мішка лівобічної пахової грижі.

2. Після розкриття та обробки грижового мішка (з резекцією його 2/3) через шийку останнього в черевну порожнину введено перший (“оптичний”) 10-міліметровий троакар.

3. Лігування грижового мішка на троакарі (герметизація черевної порожнини) та накладання карбоксиперитонеуму.

4. Малоінвазивна частина: введення трьох портів у типових точках із подальшим виконанням лапароскопічної холецистектомії.

\section{СПИСОК ЛІТЕРАТУРИ}

1. Технічні аспекти симультанних лапароскопічних операцій у хворих на жовчнокам'яну хворобу та супутню хірургічну абдомінальну патологію / М. Ю. Ничитайло, М. С. Загрійчук, I. І. Булик [та ін.] // Український журнал хірургії. - 2013. - № 2 (21). - С. 14-20.

2. Симультанні лапароскопічні операційні втручання з приводу жовчнокам'яної хвороби / М. Ю. Ничитайло, М. С. Загрійчук, І. І. Булик, О. Р. Демченко // Клінічна хірургія. 2012. - № 3. - С. 5-8.

3. Симультанні операції при виконанні лапароскопічних холецистектомій / І. В. Козань, О. З. Бойченко, Я. І. Козань, М. М. Лізанець [Електронний ресурс]. - Режим доступу : http://virgo. org.ua/index.php/naukovi-statti-ta-publikatsiji/1777-simultannioperatsiji-pri-vikonanni-laparoskopichnikh-kholetsistektomij

4. Галей М. М. Симультанні лапароскопічні операції у хворих на жовчнокам'яну хворобу та супутню хірургічну аб-
5. Видалення жовчного міхура через грижовий мішок пахової грижі після зняття “герметизуючої” лігатури (не потрібно розширювати рану).

6. Прошивне лігування залишку грижового мішка та відсічення мішка над лігатурою, герніопластика, зашивання троакарних ран.

Загальна тривалість операції - 62 хв.

Отримано патент на корисну модель № 109209 від 10.08.2016 р.

Лікування: клексан, нестероїдні протизапальні препарати, перев’язки.

Післяопераційний період перебігав без ускладнень. Активна хода мала місце з 2-ї доби післяопераційного періоду. Пацієнтку виписано 14.03.16 p. після зняття швів (хвора живе за 36 км від центральної районної лікарні).

Висновки. 1. Використання грижового мішка лівобічної пахової грижі для введення першого (оптичного) порту для виконання ЛХЕ абсолютно безпечне, скорочує тривалість симультанного комбінованого операційного втручання, не потребує розширення розрізу для видалення жовчного міхуpa із черевної порожнини; доцільне при поєднанні ЖКХ та лівобічної пахової грижі у хворих із “короткою” передньою черевною стінкою без АКО.

2. Виконання даного прийому у хворих із доліхоморфним типом тулуба та АКО I-ІІ ступенів можливе при використанні скошеної чи гнучкої оптики.

3. Використання грижового мішка лівобічної пахової грижі для введення першого порту для виконання ЛХЕ при поєднанні ЖКХ та лівобічної пахової грижі у високорослих хворих із брахіморфним чи мезоморфним типом тулуба з АКО, імовірно, недоцільне через можливу недостатню візуалізацію підпечінкового простору та елементів трикутника Кало.

4. Використання грижового мішка правобічної пахової грижі з даною метою не доцільне через порушення принципу тріангуляції інструментів (лапароскоп “0” градусів), однак можливе при використанні скошеної чи гнучкої оптики.

домінальну патологію / М. М. Галей, І. Я. Дзюбановський // Шпитальна хірургія. - 2016. - № 3. - С. 84-88.

5. Діагностика та лікування інтраопераційних і ранніх післяопераційних ускладнень при лапароскопічній холецистектомії з приводу жовчнокам’яної хвороби / А. I. Суходоля, О. О. Підмурняк, С. А. Суходоля [та ін.] // Вісник Вінницького національного медичного університету. - 2016. - Т. 20, № 1 (2). - С. 192-195.

6. Практические рекомендации E.A.E.S. по использованию пневмоперитонеума в лапароскопической хирургии / J. Neudecker ${ }^{1,2}$, S. Sauerland ${ }^{2}$, E. Neugebauer ${ }^{2}$ и группа экспертов [Электронный ресурс]. - Режим доступа : http://www. laparoscopy.ru/doktoru/eaes_pn.html

7. http://uapatents.com/4-109209-sposib-vvedennya-pershogooptichnogo-portu-pri-vikonanni-simultannikh-operacijj-ukhvorikh-z-korotkoyu-perednoyu-cherevnoyu-stinkoyu.html 


\section{REFERENCES}

1. Nychytailo, M.Yu., Zahriichuk, M.S., Bulyk, I.I., Masiuk, Yu.I., \& Homan, A.V. (2013). Tekhnichni aspekty symultannykh operatsiy u khvorykh na zhovchnokamianu khvorobu ta suputniu khirurhichnu abdominalnu patolohiiu [Technical aspects of simultaneous laparoscopic surgeries in patients with cholelithiasis and concomitant surgical abdominal pathology]. Ukrainskyi zhurnal khirurhii - Ukrainian Journal of Surgery, 2 (21) [in Ukrainian]. 2. Nychytailo, M.Yu., Zahriichuk, M.S., Bulyk, I.I., \& Demchenko, O.R. (2012). Symultanni laparoskopichni operatsiini vtruchannia z pryvodu zhovchnokamianoi khvoroby [Simultaneous laparoscopic surgical interventions regarding gallbladder disease]. Klinichna khirurhiia - Clinical Surgery, 3, 5-8 [in Ukrainian].

3. Nychytailo, M.Yu., Zahriichuk, M.S., \& Bulyk, I.I. (2013). Symultanni laparoscopichni operatsii z pryvodu zhovchnokamianoi khvoroby, zapalnykh ta kistoznykh zakhvoriuvan orhaniv cherevnoi porozhnyny [Simultaneous laparoscopic surgeries re- garding gallbladder disease, inflammatory and cyst diseases of abdominal organs]. Klinichna khirurhiia - Clinical Surgery, 4, 5-8 [in Ukrainian].

4. Kozan, I.V., Boychenko, O.Z., Kozan, Ya.I. \& Lizanets, M.M. Symultanni operatsii pry vykonanni laparoscopichnykh kholetsystektomii [Simultaneous surgeries when laparoscopic cholecystectomies] [in Ukrainian].

5. Halei, M.M., \& Dziubanovskyi, I.Ya. (2016). Symultanni laparoscopichni operatsii u khvorykh na zhovchnokamianu khvorobu ta suputniu khirurhichnu abdominalnu patolohiiu [Simultaneous laparoscopic operations in patients with gallbladder disease and concomitant surgical abdominal pathology]. Shpytalna khirurhiia - Hospital Surgery, 3, 84-88 [in Ukrainian].

6. http://uapatents.com/4-109209-sposib-vvedennya-pershogooptichnogo-portu-pri-vikonanni-simultannikh-operacijj-ukhvorikh-z-korotkoyu-perednoyu-cherevnoyu-stinkoyu.html

\title{
B. R. PANCHYSHYN
}

Slavuta Central District Hospital, Khmelnytskyi region

\section{A NEW WAY TO ENTER THE FIRST (OPTICAL) PORT WHEN PERFORMING SIMULTANEOUS OPE- RATIONS COMBINED WITH A COMBINATION OF SYMPTOMATIC GSD AND LEFT-SIDED INGUINAL HERNIA}

\begin{abstract}
The aim of the work: a new safe method of inserting the first (optical) port when performing simultaneous operations for GSD and left-sided inguinal hernia is described.

The essence of the method is in the performing of combined surgical interference, which begins with herniotomy of groin hernia and hernia sac separation. The next stage of the operation is the insertion into the abdominal cavity the first (optical) troacar through the hernia sac. The hernia sac is ligatured on the optical port to seal hermetically the abdomen and to lay pneumoperitoneum. Laparoscopic cholecystectomy is performed after insertion of 2-4 ports in typical points. The gallbladder is removed through the inguinal hernia sac. After the resection of the hernia sac is performed hernioplasty. The described method allows absolutely safely to put pneumoperitoneum, remove the gallbladder without expanding cut even with big gallstones and significantly reduce the time of two simultaneous operations.
\end{abstract}

Key words: safe pneumoperitoneum; first port; simultaneous operations; laparoscopic cholecystectomy; inguinal hernia.

\author{
Б. Р. ПАНЧИШИН
}

Славутская центральная районная больница, Хмельницкая область

\section{НОВЫЙ БЕЗОПАСНЫЙ СПОСОБ ВВЕДЕНИЯ ПЕРВОГО (ОПТИЧЕСКОГО) ПОРТА ПРИ ВЫПОЛНЕНИИ СИМУЛЬТАННЫХ КОМБИНИРОВАННЫХ ОПЕРАЦИЙ ПРИ СОЧЕТАНИИ СИМПТОМНОЙ ЖЁЛЧНОКАМЕННОЙ БОЛЕЗНИ И ЛЕВОСТОРОННЕЙ ПАХОВОЙ ГРЫЖИ}

\begin{abstract}
Цель работы: описать новый безопасный способ введения первого (оптического) порта при выполнении симультанных операций по поводу жёлчнокаменной болезни (ЖКБ) и левосторонней паховой грыжи.

Суть метода заключается в выполнении комбинированного оперативного вмешательства, которое начинается с герниотомии паховой грыжи, выделения грыжевого мешка. Следующим этапом операции является введение в брюшную полость первого (оптического) троакара через мешок грыжи. Последний завязывается лигатурой на оптическом порту для герметизации брюшной полости и наложением пневмоперитонеума. Лапароскопическая холецистэктомия выполняется после введения 2-4-го портов в типичных точках. Жёлчный пузырь выдаляется через мешок паховой грыжи. После резекции мешка проводится герниопластика. Описанный способ позволяет абсолютно безопасно наложить пневмоперитонеум, удалить жёлчный пузырь без расширения разреза даже при великих размерах жёлчных конкрементов и значительно сократить время выполнения двух одновременных операций.
\end{abstract}

Ключевые слова: безопасный пневмоперитонеум; первый порт; симультанные операции; лапароскопическая холецистэктомия; паховая грыжа. 